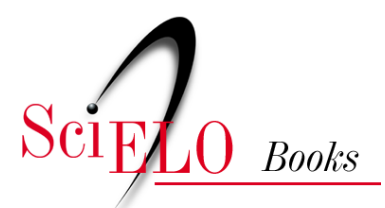

\title{
26. Fleming, o Acaso e a Observação
}

\author{
Joffre Marcondes de Rezende
}

\section{SciELO Books / SciELO Livros / SciELO Libros}

REZENDE, J. M. Fleming, o Acaso e a Observação. In: À sombra do plátano: crônicas de história da medicina [online]. São Paulo: Editora Unifesp, 2009, pp. 241-243. História da Medicina series, vol. 2. ISBN 978-85-61673-63-5. https://doi.org/10.7476/9788561673635.0027.

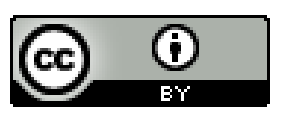

All the contents of this work, except where otherwise noted, is licensed under a Creative Commons Attribution 4.0 International license.

Todo o conteúdo deste trabalho, exceto quando houver ressalva, é publicado sob a licença Creative Commons Atribição 4.0.

Todo el contenido de esta obra, excepto donde se indique lo contrario, está bajo licencia de la licencia Creative Commons Reconocimento 4.0. 


\section{Fleming, o Acaso e a Observação}

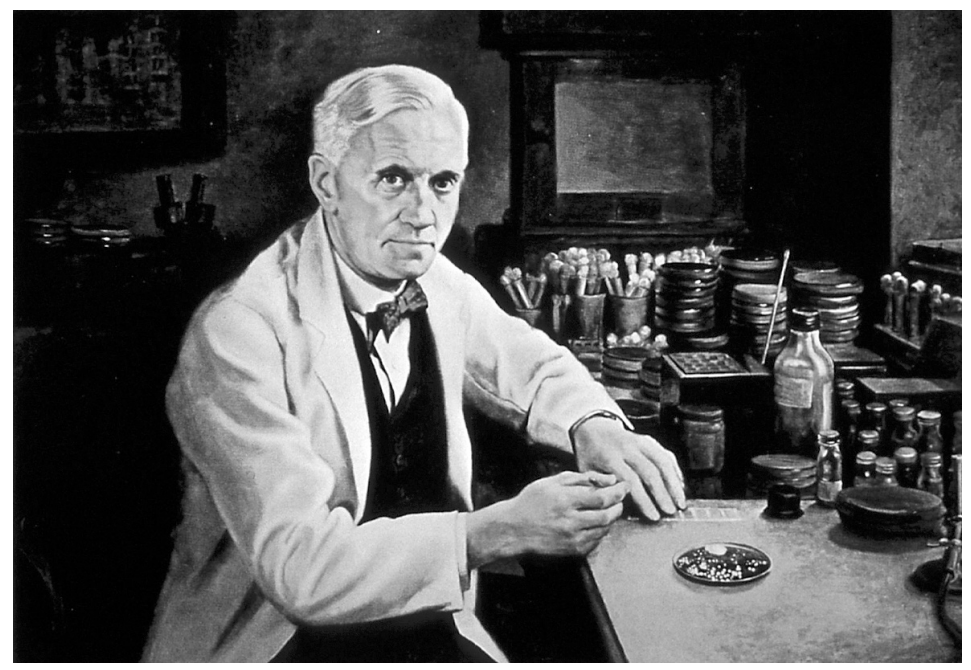

Alexander Fleming (I88I-I955).

П $\mathrm{O}$ acaso, já dizia Pasteur, só favorece os espíritos preparados e não prescinde da observação. A descoberta da penicilina constitui um exemplo típico.

Alexander Fleming, bacteriologista do St. Mary’s Hospital, de Londres, vinha já há algum tempo pesquisando substâncias capazes de matar ou impedir o crescimento de bactérias nas feridas infectadas. Essa preocupação se justificava pela experiência adquirida na Primeira Guerra Mundial (I9I4-I9I8), na qual muitos combatentes morreram em consequência da infecção em ferimentos profundos.

Em I922, Fleming descobrira uma substância antibacteriana na lágrima e na saliva, a qual dera o nome de lisozima (Maurois, I959, pp. I 20-I34).

Em I928, Fleming desenvolvia pesquisas sobre estafilococos, quando descobriu a penicilina. A descoberta deu-se em condições peculiaríssimas, graças a uma sequência de acontecimentos imprevistos e surpreendentes. 
No mês de agosto daquele ano Fleming tirou férias e deixou algumas placas com culturas de estafilococos sobre a mesa, em lugar de guardá-las na geladeira ou inutilizá-las, como seria natural (Friedman e Friedland, 200I, pp. IO2-I4O).

Quando retornou ao trabalho, em setembro, observou que algumas das placas estavam contaminadas com mofo, fato que é relativamente frequente. Colocou-as, então, em uma bandeja para limpeza e esterilização. Neste exato momento entrou no laboratório um seu colega, dr. Pryce, e lhe perguntou como iam suas pesquisas. Fleming apanhou novamente as placas para explicar alguns detalhes ao seu colega sobre as culturas de estafilococos que estava realizando, quando notou que havia, em uma das placas, um halo transparente em torno do mofo contaminante, o que parecia indicar que aquele fungo produzia uma substância bactericida. $\mathrm{O}$ assunto foi discutido entre ambos e Fleming decidiu fazer algumas culturas do fungo para estudo posterior (Maurois, op. cit., p. I37).

O fungo foi identificado como pertencente ao gênero Penicillium, donde deriva o nome de penicilina dado à substância por ele produzida. Fleming passou a empregá-la em seu laboratório para selecionar determinadas bactérias, eliminando das culturas as espécies sensíveis à sua ação.

A descoberta de Fleming não despertou inicialmente maior interesse e não houve a preocupação em utilizá-la para fins terapêuticos em casos de infecção humana até a eclosão da Segunda Guerra Mundial, em I939.

Em I940, sir Howard Florey e Ernst Chain, de Oxford, retomaram as pesquisas de Fleming e conseguiram produzir penicilina com fins terapêuticos em escala industrial, inaugurando uma nova era para a medicina - a era dos antibióticos (Singer, I99I; Phillips, I99I).

Alguns anos mais tarde, Ronald Hare, colega de trabalho de Fleming, tentou, sem êxito, "redescobrir" a penicilina em condições semelhantes às que envolveram a descoberta de Fleming. Após um grande número de experiências verificou que a descoberta da penicilina só se tornou possível graças a uma série inacreditável de coincidências:

- o fungo que contaminou a placa, como se demonstrou posteriormente, é um dos três melhores produtores de penicilina dentre todas as espécies do gênero Penicillium; 
- o fungo contaminante teria vindo pela escada do andar inferior, onde se realizavam pesquisas sobre fungos (Hare, I982, pp. I-24);

- o crescimento do fungo e dos estafilococos se fez lentamente, condição necessária para se evidenciar a lise bacteriana;

- no mês de agosto daquele ano, em pleno verão, sobreveio uma inesperada onda de frio em Londres, que proporcionou a temperatura ideal ao crescimento lento da cultura;

- a providencial entrada do dr. Pryce no laboratório permitiu que Fleming reexaminasse as placas contaminadas e observasse o halo transparente em torno do fungo, antes de sua inutilização.

Apesar de todas essas felizes coincidências, se Fleming não tivesse a mente preparada não teria valorizado o halo transparente em torno do fungo e descoberto a penicilina.

\section{Referências Bibliográficas}

Friedman, M. \& Friedland, G. W. As Dez Maiores Descobertas da Medicina. São Paulo, Companhia das Letras, 200I.

Hare, R. "New Light on the History of Penicilin”. Medical History, 26, pp. I-24, I 982. Maurois, A. The Life of Sir Alexander Fleming. Chicago, Penguin Books, I959.

Phillips, J. R. "Emest Bons Chain-I945”. In Magill, F. N. The Nobel Prize Winners. Physiology or Medicine. Pasadena, Salem Press, I99I.

Singer, S. S. “Baron Florey-I945”. In Magill, F. N. The Nobel Prize Winners. Physiology or Medicine. Pasadena, Salem Press, I99I.

Sokoloff, B. The Story of Penicilin. Chicago, Ziff-Davis, I 945. 
